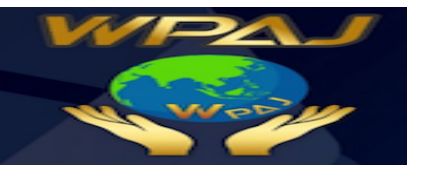

Volume 1 Issue 2, Desember 2019

https:// ejournal.unsub.ac.id/index.php/publik

\title{
Efektifitas Program Peningkatan Kapasitas Aparatur Pemerintah Desa Oleh Dinas Pemberdayaan Masyarakat dan Desa Kabupaten Subang
}

\author{
Kusman Yuhana ${ }^{1}$ \\ Fakultas Ilmu Administrasi Universitas Subang \\ kusmanyuhana.jurnal@gmail.com \\ Tony Pathony ${ }^{2}$ \\ Fakultas Ilmu Administrasi Universitas Subang \\ tonypathony.jurnal@gmail.com
}

\begin{abstract}
Abstrak
Penelitian ini berjudul Efektivitas Program Peningkatan Kapasitas Aparatur Pemerintah Desa oleh Dinas Pemberdayaan Masyarakat dan Desa Kabupaten Subang, karena diduga masih rendahnya kemampuan aparatur pemerintah desa dalam pengelolan penyusunan kebijakan desa dan manajemen pelayanan desa. Metode penelitian yang digunakan metode deskriptif dengan pendekatan kualitatif. Whitney dalam Nazir (2003: 63) mengatakan bahwa metode deskriptif ini merupakan pencarian fakta dengan interpretasi yang tepat. Hasil penelitian menunjukan bahwa Efektivitas Program Peningkatan Kapasitas Aparatur Pemerintah Desa oleh Dinas Pemberdayaan Masyarakat dan Desa Kabupaten Subang belum sepenuhnya efektif, belum sesuai dengan dimensi yang ada atau yang ditentukan. Program Peningkatan Kapasitas Aparatur Pemerintah Desa belum berjalan seperti yang diharapkan. Terutama pada dimensi produksi dan efisiensi.
\end{abstract}

Kata Kunci : Efektivitas, Program, Kapasitas

\section{Abstract}

This study is entitled The Effectiveness of the Village Government Apparatus Capacity Building Program by the Subang District Community and Village Empowerment Office, due to the alleged low ability of village government officials in managing village policy formulation and village service management. The research method used is descriptive method with a qualitative approach. Whitney in Nazir (2003: 63) says that this descriptive method is a fact finding with the right interpretation. In this study the analysis used is data reduction, data presentation and conclusion. The results showed that the effectiveness of the Village Government Apparatus 
Capacity Building Program by the Subang District Community Empowerment and Village Agency was not yet fully effective, not in accordance with the existing or determined dimensions. The Village Government Apparatus Capacity Building Program has not gone as expected. Especially on the dimensions of production and efficiency.

Keywords: Effectiveness, Program, Capacity

\section{Pendahuluan}

Pembangunan pada dasarnya diselenggarakan oleh pemerintah daerah, maka pemerintah daerah diberi kesempatan untuk mengurus sendirie masalah yang terdapat dipemerintah sesuai dengan otonomi dan tugas pembantuan. Pelaksanaan otonomi daerah tersebut dengan memperhatikan aspek-aspek hubungan antara susunan pemerintah pusat dan pemerintah daerah, potensi dan keanekaragaman daerah, peluang dan tantangan persaingan global dengan memberikan kewenangan yang seluas-luasnya kepala daerah disertai dengan pemberian hak dan kewajiban menyelanggarakan otonomi daerah kesatuan system penyelenggaraan pemerintah daerah.

Dalam kaitanya dalam pelaksanaan otonomi daerah, Desa sebagai struktur organisasi pemerintahan paling rendah menjadi garda terdepan pelayanan yang langsung bersentuhan dengan masyarakat. Oleh sebab itu, kemampuan dan kapasitas aparatur pemerintah desa memegang peranan yang sangat penting. Dengan kompleksitas permasalahan yang di hadapinya, aparatur desa di tuntut untuk memiliki perhatian dan tanggung jawab terhadap masyarakat desa. Disebutkan dalam Undangundang Nomor 6 Tahun 2014 bahwa desa dan desa adat atau yang di sebut dengan nama lain, selanjutnya disebut desa, adalah kesatuan masyarakat hukum yang memiliki batas wilayah yang berwenang untuk mengatur dan mengurus urusan pemerintahan, kepentingan masyarakat setempat berdasarkan prakarsa masyarakat, hak asal usul, dan/atau hak tradisional yang diakui dan dihormati dalam sistem pemerintahan Negara Kesatuan Republik Indonesia.Pemerintah desa sebagai bagian dari sistem sosial memiliki peran yang sangat penting dalam pengelolaan modal sosial yang dimiliki oleh masyarakat (Sururi, 2018). Modal sosial masyarakat berupa nilai-nilai tradisional, kearifan lokal, sosial dan budaya serta kehidupan gotong royong merupakan perpaduan yang kokoh masyarakat dalam menghadapi permasalahan di tengah perubahan dan dinamika global. Meskipun demikian kekuatan modal sosial tersebut perlu didukung dengan penyelengaraan administrasi pemerintahan desa dan laporan keuangandesa yang tertib dalam rangka pelaksanaan pembangunan, pembinaan kemasyarakatan dan pemberdayaan masyarakat.

Dalam melaksanakan penyelenggaraan administrasi pemerintahan desa dan laporan keuangan desa yang tertib tersebut diperlukan aparatur pemerintahan desa yang mampu dan memiliki kapasitas. Berdasarkan hasil analisis ditemukan 
pemasalahan masih rendahmya kemampuan aparatur pemerintah desa dalam pengelolaan penyusunan kebijakan desa dan manajemen pelayanan desa sehingga menghambat penyusunan perencanaan. Dalam hal ini, keberadaan program sebagai fasilitator masih belum dapat memberikan daya dukung terhadap peningkatan kapasitas aparatur pemerintah desa. Dalam konteks penyelenggaraan pemerintahan daerah yang terpenting adalah bagaimana pemerintahan desa mampu meningkatkan kesejahteraan rakyatnya, mampu memberikan pelayanan kepada masyarakat desa, mampu meningkatkan daya saing desanya LAN-RI dalam Sururi (2018: 69). Oleh sebab itu, peningkatan kapasitas aparatur desa dalam tata kelola administrasi pemerintahan desa menjadi hal yang sangat penting.

Sebagaimana amanat Undang-undang Nomor 23 Tahun 2014 Tentang Pemerintahan Daerah yang di dalamnya mewajibkan adanya urusan pemberdayaan masyarakat dan desa kemudian dijabarkan pada peraturan pemerintah Nomor 18 Tahun 2016 Tentang Perangkat Daerah yang mendorong segera dibentuk perangkat Daerah dengan mendekatkan pada posisi ideal ramping struktur kaya fungsi, maka dibuatlah Peraturan Daerah Nomor 7 tahun 2016 Tentang Pembentukan dan Susunan Perangkat Daerah Kabupaten Subang yang melahirkan salah satunya Dinas Pemberdayaan Masyarakat dan Desa Kabupaten Subang. Dinas Pemberdayaan Masyarakat dan Desa merupakan pecahan dari Badan Pemberdayaan Masyarakat dan Keluarga Berencana dimana sebelumnya mengelola tiga urusan besar yaitu urusan pemberdayaan masyarakat, urusan keluarga berencana dan urusan pemberdayaan perempuan, sekarang lebih fokus pada satu urusan yaitu urusan wajib non pelayanan dasar urusan pemberdayaan masyarakat dan desa dengan konsekuensi kalau dulu pengelolaan pemerintahan desa ada pada bagian pemerintahan sekretariat daerah sekarang menjadi bagian urusan pada Dinas Pemberdayaan Masyarakat dan Desa. (Sumber: Dinas Pemberdayaan Masyarakat dan Desa Kabupaten Subang 2018)

Sebagai mana yang tertera pada Peraturan Bupati Subang Nomor: 66 tahun 2016 pada paragraf 3 Bidang Pemerintahan Desa/Kelurahan, pada Pasal 9 Bidang Pemerintahan Desa/Kelurahan mempunyai tugas pokok menyeleggarakan perumusan dan pelaksanaan teknis kebijakan pemerintahan Desa/kelurahan, serta Penyusunan Program kerja di Bidang Pemerintahan Desa/Kelurahan, maka dari itu sesuai amanat Peraturan Bupati Dinas Pemberdayaan Masyarakat dan Dan desa Kabupaten Subang mempunyai kewajiban untuk menyusun Program di bidang Pemerintahan Desa/Kelurahan serta menjalankan program Peningkatan Kapasitas Aparatur Pemerintah Desa.

Berdasarkan data dinas pemberdayaan masyarakat dan desa kabupaten subang didapatkan masih relatif terbatasnya kemampuan pembangunan desa dalam mengefektifkan penyelenggaraan pemerintah desa dalam rangka penyelenggaraan pemerintahan, lalu pelaksanaan pembangunan, masih belum memberikan kepuasan terhadap masyarakat dari sisi kemudahan dan kecepatan pelayanan yang diberikan, selanjutnya pembangunan infrastruktur oleh pemerintah desa sudah dilakukan sampai dengan saat ini meskipun masih belum menyentuh aspek kebutuhan dasar masyarakat, dan desain kelembagaan masih menggunakan pola tradisional. Persoalan-persoalan 
yang menyangkut aspek Aparatur Desa di lingkungan Pemerintah Desa (Kepala Desa dan perangkatnya). Dalam peraturan perundangan tentang Desa disebutkan bahwa perangkat desa diangkat oleh Kepala Desa dari penduduk desa. Pemilihan dan pengangkatan perangkat desa (kecuali sekretaris desa/Sekdes) belum sepenuhnya didasarkan pada pertimbangan kompetensi. Ada dua alasan terkait hal ini, Pertama, Kepala Desa terpilih menunjuk/memilih keluarga atau orang-orang terdekat untuk menduduki jabatan perangkat desa, yang terkadang tanpa mempertimbangkan kemampuannya; Kedua, karena memang tidak ada lagi orang yang mau dan mampu menjadi perangkat desa. Dalam pelaksanaan Dinas Pemberdayaan Masyarakat dan Desa Kabupaten Subang hanya sebagai fasilitator dan bekerja sama dengan pihakpihak yang terkait dalam program peningkatan kapasitas aparatur pemerintah desa salah satunya bekerjasama dengan tenaga ahli di bidang akademis sehingga pelaksanaan program peningkatan kapasitas aparatur pemerintah desa diwilayah kabupaten Subang dapat terlaksana dengan baik. Tidak dapat dipungkiri banyak hal yang dihadapi dalam pelaksanaan program tersebut antara lain personil desa yang berganti-ganti dikarenakan berbagai faktor yang salah satunya ketidak cocokan antara aparatur desa dengan kepala desanya atau sebaliknya kepala desa yang tidak cocok dengan aparatur desa yang lama dan banyak faktor lain nya. Berdasarkan hasil penelitian yang dilakukan, dapat diketahui bahwa program Peningkatan Kapasitas Aparatur Pemerintah Desa belum efektif.

\section{Kerangka Teori}

\section{a. Pengertian Efektivitas}

Dalam suatu organisasi dapat di ukur tingkat keberhasilanya dengan mengamati efektif tidaknya organisasi tersebut dalam menjalankan tugasnya. Kata efektif berasal dari bahasa inggris yaitu effectiveyang berarti berhasil atau sesuatu yang dilakukan berhasil dengan baik. Menurut pasolong (2007: 4) efektivitas pada dasarnya berasal dari kata "efek" dan digunakan istilah ini sebagai hubungan sebab akibat. Efektivitas dapat di pandang sebagai suatu sebab dari variable lain. Efektivitas berarti bahwa tujuan yang telah direncanakan sebelumnya dapat tercapai atau dengan kata sasaran tercapai karena adanya proses kegiatan. Hal ini sesuai menurut Richard Steer (2003: 46) Efektivitas adalah sejauhmana organisasi melaksanakan seluruh tugas pokoknya atau mencapai suatu sasaranya. Penilaian umum dengan sebanyak mungkin kriteria tunggal dalam menghasilkan penilaian yang umum mengenai efektivitas organisasi. Selanjutnya menurut $\mathrm{H}$. Emerson dalam Soewarno Handayaningrat (2006: 16) yang menyatakan bahwa Efektifitas adalah pengukuran dalam arti tercapainya tujuan yang telah ditentukan sebelumnya. Pengertian efektivitas sebenarya bersifat abstrak, namun akan menadi konkrit dan dapat di ukur apabila mampu untuk mengidentifikasi segisegi yang lebih menonjol atau nampak yang berhubungan dengan konsep efektivitas. Adapun pengertian efektivitas menurut The Liang Gie, (2002: 147) 
adalah sebagai berikut: "Efektivitas adalah suatu keadaan yang mengandung pengertian mengenai terjadinya efek akibat yang dikehendaki, kalau seseorang melakukan perbuatan dengan maksud tertentu yang memang dikehendaki, maka orang tersebut dikatakan efektif, kalau menimbulkan akibat atau mempunyai maksud sebagaimana dikehendaki." Kemudian menurut Sutarto (2007: 95), mengatakan bahwa efektivitas adalah suatu keadaan dimana aktivitas-aktivitas jasmaniah dan rohaniah yang dilakukan oleh manusia untuk mencapai hasil sesuai dengan yang dikehendaki. Dalam penelitian ini yang dimaksud dengan efektivitas adalah derajat pencapaian tujuan organisasi dari sejumlah aktivitas jasmaniah dan rohaniah yang di lakukan oleh pegawai. Menurut Siagian (2006: 24) memberikan definisi efektivitas sebagai berikut: Efektivitas adalah pemanfaatan sumber daya, sarana dan prasarana dalam jumlah tertentu yang secara sadar ditetapkan sebelumnya untuk menghasilkan sejumlah barang atau jasa kegiatan yang dijalankanya. Sedangkan menurut Georgopoulos dan Tennenbaum (2005: 50) mengemukakan bahwa Efektifitas adalah jangkauan usaha suatu program sebagai suatu system dengan sumberdaya dan sarana tertentu untuk memenuhi tujuan dan sasaranya tanpa melumpuhkan cara dan sumberdaya itu serta tanpa memberi tekanan yang tidak wajar terhadap pelaksananya.

Dari beberapa pendapat di atas, dapat disimpulkan bahwa suatu pekerjaan dapat dilaksanakan secara tepat, efektif, efisien apabila pekerjaan tersebut dilaksanakan secara tepat sesuai dengan yang telah di rencanakan. Efektivitas menunjukan keberhasilan dari segi tercapai tidaknya sasaran yang telah ditetapkan, jika hasil kegiatanya semakin mendekati sasaran berarti semakin tinggi efektivitasnya. Mengacu pada penjelasan di atas, maka untuk mencapai tujuan organisasi secara efektif perlu adanya harmonisasi kemampuan sumber daya dengan menggunakan sarana yang lain sehingga sasaran yang akan dicapai menjadi jelas. Pencapaian sasaran tersebut dapat dikatakan efektif apabila ada keharmonisan. Setiap pekerjaan pegawai dalam organisasi sangat menentukan bagi pencapaian hasil kegiatan seperti yang telah direncanakan terlebih dahulu. Untuk itu factor keefektifanya banyak mempengaruhi kepada kemampuan aparatur dan organisasi dalam melaksanakan tugas dan kewenanganya. Tingkat pencapaian tujuan aparatur dalam suatu organisasi dikatakan efektif apabila pencapaian itu sesuai dengan tujuan organisasi dan memberikan hasil yang bermanfaat.

\section{b. Ukuran Efektivitas}

Mengukur efektivitas organisasi bukanlah suatu hal yang sangat sederhana, karena efktivitas dapat dikaji dari berbagai sudut pandang dan tergantung pada siapa yang menilai serta mengintepretasikannya. Tingkat efektivitas juga dapat diukur dengan membandingkan antara rencana yang telah ditentukan dengan hasil nyata yang telah diwujudkan. Namun, jika usaha atau hasil pekerjaan dan tindakan yang dilakukan tidak tepat sehingga menyebabkan tujuan tidak tercapai, maka hal itu dikatakan tidak efektif. Adapun kriteria atau ukuran mengenai 
pencapaian tujuan efektif atau tidak, sebagaimana dikemukakan oleh siagian (2008: 77), yaitu:

a) Kejelasan tujuan yang hendak dicapai, hal ini dimaksudkan supaya karyawan dalam pelaksana tugas mencapai sasaran yang terarah dan tujuan organisasi dapat tercapai.

b) Kejelasan strategi pencapaian tujuan, telah diketahui bahwa strategi adalah "pada jalan" yang diikuti dalam melakukan berbagai upaya dalam mencapai sasaran-sasran yang ditentukan agar para implementer tidak tersesat dalam pencapaian organisasi.

c) Proses analisis dan perumusan kebijakan yang mantap,berkaitan dengan tujuan yang hendak dicapai dan strategi, yang telah ditetapkan artinya kebijakan harus mampu menjembatani tujuan-tujuan dengan usaha-usaha pelaksanaan kegiatan operasional.

d) Perencanaan yang matang, pada hakekatnya berarti memutuskan sekarang apa yang dikerjakan organisasi di masa depan.

e) Penyusunan program yang tepat, suatu rencana yang baik masih perlu dijabarkan dalam program-program pelaksanaan yang tepat sebab apabila tidak, para pelaksana akan kurang memiliki pedoman bertindak dan bekerja.

f) Tersedianya sarana dan prasarana kerja, salah satu indicator efektivitas organisasi adalah kemampuan bekerja secara produktif. Dengan sarana dan prasarana yang tersedia dan mungkin disediakan oleh organisasi.

g) Pelaksanaan yang efektif dan efisien, bagaimana baiknya suatu program apabila tidak dilaksanakan secara efektif dan efisien maka organisasi tersebut tidak akan mencapai sasaranya, karena dengan pelaksanaan organisasi semakin didekatkan pada tujuanya.

h) System pengawasan dan pengendalian yang bersifat mendidik mengingat sifat manusia tidak sempurna maka efektifitas organisasi menuntut terdapatnya system pengawasan dan pengendalian.

Menurut Steers dalam tangkilisan (2005: 141) mengemukakan 5 (lima) kriteria dalam pengukuran efektivitas, yaitu: Produktifitas, Kemampuan adaptasi kerja, Kemampuan berlaba, Pencarian sumberdaya. Menurut Gibson (2002: 32) disebutkan bahwa indikator untuk menentukan efektivitas organisasi adalah :

1) Produksi (prodiction)

2) Produksi merupakan kriteria efektivitas yang mengacu pada ukuran keluaran utuma dari organisasi. Ukuran dari produksi mencakup tentang dokumen yang di proses, rekaman yang dilayani, dan sebagainya. Ukuran tersebut memiliki hubungan secara langsung dengan masyarakat pengguna layanan dan rekanan oerganisasi yang bersangkutan.

3) Efisiensi (efficiency)

4) Efisiensi merupakan kriteria efektivitas mengacu pada ukuran penggunaan sumber daya yang langka oleh organisasi. Efisiensi merupakan perbandingan (rasio) Antara output dan input. Ukuran efisiensi terdiri dari biaya per unit, pemborosan, waktu terluang, biaya per orang, dan sebagainya efesiensi 
diukur berdasarkan rasio Antara keuntungan dengan biaya atau waktu yang digunakan.

5) Kepuasan (satisfaction)

6) Kepuasan merupakan kriteria efektivitas yang mengacu pada keberhasilan organisasi dalam memenuhi kebutuhan karyawan dan anggota-anggota organisasi tersebut. Ukuran dari kepuasan meliputi sikap karyawan, penggantian karyawan, absensi, kelambanan, keluhan, kesejahteraan, dan sebagainya.

7) Adaptasi (adaptiveness)

8) Kemampuan adaptasi merupakan kriteria efektivitas yang mengacu pada tanggapan organisasi terhadap perubahan eksternal dan internal. Perubahanperubahan eksternal seperti persaingan, keinginan para pelanggan, kualitas produk, dan sebagainya serta perubahan internal seperti ketidakefisienan, ketidakpuasan, dan sebagainya merupakan adaptasi terhadap lingkungan.

9) Perkembangan (development)

10) Organisasi harus menginvestasi dalam organisasi itu sendiri untuk memperluas kemampuanya untuk hidup terus (survive) dalam jangka panjang. Usaha pengembangan yang biasa adalah program pelatihan bagi tenaga manajemen dan non manajemen, tetapi sekarang ini pengembangan organisasi untuk bertambang banyak macamnya dan meliputi sejumlah pendekatan psikologis dan sosiologis.

Membahas masalah ukuran efektivitas memang sangat bervariasi tergantung dari sudut terpenuhunya beberapa kriteria akhir. Menurut pendapat steers (2005:

46) menyebutkan beberapa ukuran dari efektivitas, yaitu:

1) Kualitas artinya kualitas yang dihasilkan oleh organisasi;

2) Produktivitas artinya kuantitas dari jasa yang dihasilkan;

3) Kesiagaan yaitu penilaian menyeluruh sehubungan dengan kemungkinan dalam hal penyelesaian suatu tugas khusus dengan baik;

4) Efisiensi merupakan perbandingan beberapa aspek prestasi terhadap biaya untuk menghasilkan prestasi tersebut;

5) Penghasilan yaitu jumlah suber daya yang masih tersisa setelah semua biaya dan kewajiban dipenuhi;

6) Pertumbuhan adalah suatu perbandingan mengenai eksistensi sekarang dan masa lalunya;

7) Stabilitas yaitu pemeliharaan struktur, fungsi dan sumber daya sepanjang waktu;

8) Kecelakaan yaitu frekuensi dalam hal perbaikan yang berakibat pada kerugian waktu;

9) Semangat kerja yaitu adanya perasaan terikat dalam hal pencapaian tujuan, yang melibatkan usaha tambahan, kebersamaan tujuan dan perasaan memiliki;

10) Motivasi artinya ada kekuatan yang muncul dari setiap individu untuk mencapai tujuan; 
11) Kepaduan yaitu fakta bahwa para anggota organisasi saling menyukai satu sama lain, artinya bekerja sama dengan baik, berkomunikasi dan mengkoordinasikan;

12) Keluwesan Adaptasi artinya adanya suatu rangsangan baru untuk mengubah prosedur standar operasinya, yang bertujuan untuk mencegah keterbukaan terhadap rangsangan lingkungan;

Sehubungan dengan hal-hal yang dikemukakan di atas, maka ukuran efektivitas merupakan suatu setandar akan terpenuhunya mengenai sasaran dan tujuan yang akan dicapai serta menunjukan pada tingkat sejauhmana organisasi, program/kegiatan melaksanakan fungsi-fungsinya secara optimal. Mengacu pada penjelasan di atas dapat disimpulkan bahwa kriteria pengukuran efektivitas, meliputi: kriteria efektivitas jangka pendek (efisiensi, kepuasan) dan kriteria efektivitas jangka panjang (kelangsungan hidup). Dengtan mempertimbangan dimensi waktunya, organisasi dapat dikatakan efektif dari segi kriteria produktivitas, kepuasan, adaptasi, dan pengembangan.

Menurut Martani dan Lubis (2007: 55) pendekatan pengukuran efektivitas organisasi dapat diukur dengan indikator:

1) Efisiensi

2) Efisiensi merupakan suatu ukuran keberhasilan yang di nilai dari segi besarnya sumber/biaya dan waktu untuk mencapai hasil dari kegiatan yang dijalankan.

3) Daya Tanggap Petugas

4) Keinginan untuk melayani masyarakat secara tepat dengan baik mengulurulur waktu. Saat pengguna layanan membutuhkan pelayanan. Maka penyedia layanan segera memberikan pelayanan tanpa harus menunggu lama.

5) Sarana dan Prasarana

6) Secara umum sarana dan prasarana adalah alat penunjang keberhasilan suatu proses upaya yang dilakukan di dalam pelayanan publik, karena apabila kedua hal ini tidak tersedia maka semua kegiatan yang dilakukan tidak akan dapat mencapai hasil yang diharapkan sesuai dengan rencana.

7) Semangat Kerjasama dan Loyalitas Kelompok

8) Setiap organisasi selalu berusaha agar produktivitas kerja karyawan dapat ditingkatkan. Untuk itu pimpinan perlu mencari cara dan solusi guna menimbulkan semangat kerja para karyawan. Hal itu penting, sebab semangat kerja mencerminkan kesenangan yang mendalam terhadap pekerjaan yang dilakukan sehingga pekerjaan lebih cepat dapat diselesaikan dan hasil yang lebih baik dapat dicapai.

9) Hubungan Antara Pimpinan dan Bawahan

10) Hubungan Antara pimpinan dan pegawai berpengaruh untuk menciptakan suasana kerja yang kondusif, sehingga pekerjaan menjadi lebih mudah dan lancar. 


\section{c. Faktor-Faktor yang mempengaruhi Efektivitas}

Menurut pendapat Steers dalam Sutrisno (2011: 148) menyebutkan bahwa ada empat factor yang mempengaruhi Efektivitas, yaitu :

1) Karakteristik Organisasi, adalah hubungan yang sifatnya relatif tetap seperti susunan sumber daya manusia yang terdapat dalam organisasi. Struktur merupakan cara yang unik menempatkan manusia dalam rangka menciptakan sebuah organisasi. Dalam struktur, manusia ditempatkan sebagai bagian dari suatu hubungan yang relative tetap yang akan menentukan pola interaksi dan tingkah laku yang berorientasi pada tugas.

2) Karakteristik Lingkungan, mencakup dua aspek. Aspek pertama adalah lingkungan ekstern yaitu lingkungan yang ada diluar batas organisasi dan sangat berpengaruh terhadap organisasi. Aspek kedua adalah lingkungan intern yang dikenal sebagai iklim organisasi yaitu lingkungan secara keseluruhan di dalam lingkungan organisasi.

3) Krakteristik Pekerja, merupakan factor yang paling berpengaruh terhadap efektivitas. Didalam diri setiap individu akan ditemukan banyak perbedaan, akantetapi kesadaran individu terhadap perbedaan itu sangat penting dalam tujuan pencapaian tujuan organisasi. Jadi apabila suatu organisasi menginginkan keberhasilan, organisasi tersebut harus dapat mengintegrasikan tujuan individu dengan tujuan organisasi

4) Karakteristik Kebijaksanaan dan Praktek Manajemen, ada strategi mekanisme kerja yang dirancang untuk mengkondisikan semua hal yang ada didalam organisasi sehingga efektivitas organisasi dapat tercapai. Kebijakan dan peraktek manajemen merupakan alat bagi pimpinan untuk mengarahkan setiap kegunaan guna mencapai tujuan organisasi.

5) Hal di atas berpengaruh terhadap efektivitas organisasi, karena faktor tersebut menyangkut para pekerja yang cenderung lebih terikat pada organisasi dan merasa lebih puas jika mereka mempunyai kesempatan mendapat tanggung jawab yang lebih besar dan mengandung lebih banyak variasi jika pereturan dan ketentuan yang ada dibatasi seminimal mungkin.

\section{Metodologi Penelitian}

Penelitian tentang Efektivitas Program Peningkatan Kapasitas Aparatur Pemerintah Desa oleh Dinas Pemberdayaan Masyarakat dan Desa Kabupaten Subang merupakan penelitian yang menggunakan metode deskriptif dengan pendekatan kualitatif. Metode penelitian kualitatif digunakan untuk mendapatkan data yang mendalam, suatu data yang mengandung makna atau data yang sebenarnya, penelitian kualitatif tidak begitusaja mencari kebenaran, tetapi pada pemahaman terhadap apa yang diteliti. Menurut whitney 1960 dalam Nazir (2011: 54) Metode deskriptif adalah pencarian fakta dengan interpretasi yang tepat, secara harafiah metode deskriptif adalah metode penelitian untuk membuat gambaran mengenai situasi atau kejadian, 
sehingga metode ini berkehendak mengadakan akumulasi data dasar belaka Nazir (2011: 55). Menurut Creswell dalam Satori dan Komariah (2010: 24) bahwa penelitian kualitatif adalah suatu proses inquiry tentang pemahaman berdasar pada tradisi-tradisi metodologis terpisah, jelas pemeriksaan bahwa menjelajah suatu masalah social atau manusia. Peneliti membangun suatu kompleks, gambaran, holistic, meneliti kata-kata, laporan-laporan, memerinci pandangan-pandangan, dari penutur asli, dan melakukan studi di suatu pengaturan yang alami

\section{Hasil dan Pembahasan}

\section{Gambaran Umum Dinas Pemberdayaan Masyarakat dan Desa}

Dinas Pemberdayaan Masyarakat dan Desa merupakan pecahan dari Badan Pemberdayaan Masyarakat dan Keluarga Berencana dimana sebelumnya mengelola tiga urusan besar yaitu urusan pemberdayaan masyarakat, urusan keluarga berencana dan urusan pemberdayaan perempuan, sekarang lebih fokus pada satu urusan yaitu urusan wajib non pelayanan dasar urusan pemberdayaan masyarakat dan desa dengan konsekuensi jika dulu pengelolaan pemerintahan desa ada pada bagian pemerintahan sekretariat daerah sekarang menjadi bagian urusan pada Dinas Pemberdayaan Masyarakat dan Desa.

\section{Tugas Pokok}

Dinas mempunyai tugas pokok membantu Bupati melaksanakan urusan pemerintahan dibidang Pemberdayaan Masyarakat dan Desa yang menjadi kewenangan daerah dan tugas pembantuan yang diberikan kepada Pemerintah Kabupaten.

Faktor yang sangat penting dalam upaya meningkatkan segala aktivitas organisasi adalah adanya manusia sebagai pegawai, karena tanpa adanya pegawai maka organisasi tersebut tidak akan berjalan bahkan tidak akan ada. Hal ini disebabkan karena terbentuknya suatu organisasi sebagai wadah untuk berfikir dari pada manusia.

Disamping itu pula faktor pegawai dalam suatu organisasi sangat fundamental terhadap proses pencapaian tujuan organisasi tersebut. Dapat dikatakan juga keberhasilan suatu organisasi atau berhasil tidaknya suatu organisasi tergantung pada bagaimana caranya pegawai itu sendiri mengelolanya. Kenyataanya seringmenunjukan bahwa sering terjadi suatu organisasi mengalami satu kehancuran sebagai akibat dari kesalahan dari pegawainya dalam mengelola dan melaksanakan tugas yang telah dibebankan kepadanya. Sebaliknya disisi lain sering pula terjadi suatu organisasi bekembang dengan baik hal itupun akibat dari adadanya para pegawai yang benarbenar menjalankan tugasnya dengan baik dan penuh tanggung jawab, hal itu tentunya dilihat dari sejumlah aktivitas para pegawai itu sendiri dalam mengelola organisasi.

Demikian juga dengan organisasi Dinas Pemberdayaan Masyarakat dan Desa Kabupaten Subang, pegawai merupakan alat penting dalam rangka melaksanakan tugas-tugas pemerintahan dan pembangunan Dinas Pemberdayaan Masyarakat dan 
Desa Kabupaten Subang untuk dapat melaksanakan tugas yang menjadi beban dan tanggung jawabnya sehingga pelaksanaan tugas sesuai dengan tujuan yang ingin dicapai sebelumnya.

\section{Efektivitas Program Peningkatan Kapasitas Aparatur Pemerintah Desa Oleh Dinas Pemberdayaan Masyarakat Dan Desa Kabupaten Subang}

Efektivitas merupakan tujuan yang telah direncanakan sebelumnya dapat tercapai atau sasaran tercapai karena adanya proses kegiatan. Untuk itu Dinas Pemberdayaan Masyarakat dan Desa Kabupaten Subang dituntut untuk menunjukan konsistensinya, sehingga Dinas Pemberdayaan Masyarakat dan Desa dibutuhkan ditengah-tengah masyarakat. Untuk menjalankan efektivitas program Peningkatan Kapasitas Aparatur Pemerintah Desa dengan efektif, maka harus disertai atau didukung oleh sumberdaya manusia yang terampil dibidangnya serta sarana dan prasarana yang memadai.

Selain itu efektivitas dapat digunakan untuk mengukur keberhasilan individu atau organisasi dan berikut ini pengukuran efektivitas Program Peningkatan Kapasitas Aparatur Pemerintah Desa yang dikaitkan dengan indikator efektivitas menurut Gibson (2002 : 32) kemudian dibuktikan dengan hasil wawancara dengan organisasi Dinas Pemberdayaan Masyarakat dan Desa Kabupaten Subang, Kemudian Desa berdasarkan letak Geografis antara lain, Desa Cipancar Kecamatan Serangpanjang Desa ini dipilih karena mewakili Desa di wilayah pegunungan, Desa Compreng Kecamatan Compreng Desa ini dipilih karena mewakili wiayah pertanian, serta Desa Rancadaka Kecamatan Pusakanagara Desa ini dipilih karena mewakili Desa di wilayah pesisir. Berikut ini indikator pengukuran efektivitas menurut teori Gibson ((2002 : 32).

\section{Produksi}

Produksi merupakan kriteria efektivitas yang mengacu pada ukuran keluaran utuma dari organisasi. Ukuran dari produksi mencakup tentang dokumen yang di proses, rekaman yang dilayani, dan sebagainya. Ukuran tersebut memiliki hubungan secara langsung dengan masyarakat pengguna layanan dan organisasi yang bersangkutan.

Berkaitan dengan produksi program peningkatan kapasitas aparatur pemerintah desa oleh dinas pemberdayaan masyarakat dan desa kabupaten subang peneliti berpendapat bahwa dari segi output yang dihasilkan belum sesuai dengan apa yang diharapkan masih banyaknya kendala. Dan berikut ini dibuktikan dengan kutipan wawancara dengan Dadan Dwiyana, A.P., M.Si. sebagai kepala bidang pemerintahan desa dan kelurahan pada tanggal 25 oktober 2019 pada pukul 09.00 WIB mengatakan :

"dari segi hasil pembinaan meskipun program peningkatan kapasitas aparatur pemerintah desa telah dilaksanakan akibat kebijakan politik kepala desa baru yang terpilih seringkali merombak aparatur desa yang sudah lama dengan yang baru membuat hasil pelatihan yang telah dilakukan kembali menjadi 0 lagi" 
Masih berkaitan dengan wawancara diatas berikut wawancara dengan, Mita S.AN selaku kasi tata pemerintahan desa dan kelurahan yang diwawancarai pada tanggal 25 oktober 2019 pada puku 10.00 WIB mengatakan:

"kita sudah mengantisipasi hal itu dengan sebelum pelaksanaan pilkades melaksanakan bimbingan teknis terhadap calon kepala desa agar dalam pelaksanaan di mana seseorang calon terpilih sebagai kepala desa jangan sampai merubah system tatan yang ada tapi faktanya memang tidak bisa tak kala ada yang menghambat pada kinerja dia maka akan di geser posisinya itulah nah itu mangkanya sering dirubah aparatur desa dan akhirnya staf yamg baru belum tau sitem kerja dan yang lama karena sakit hati posisinya di geser dokumen dokumen juga dihilangkan"

Dari hasil wawancara tersebut diatas, bahwa dinas pemberdayaan masyarakat dan desa dengan program peningkatan kapasitas aparatur pemerintah desa sudah berusaha mengantisipasi hal tersebut dengan cara bimbingan teknis terhadap calon kepala desa sebelum diadakanya pemilihan kepala desa. Tidak bisa dipungkiri walaupun sudah dilaksanakanya bimbingan teknis pada calon kepala desa namun kenyataanya tetap saja kepala desa tidak sertamerta mengikuti apa yang sudah diarahkan, seharusnya ada peraturan yang tegas yang mengatur pergantian aparatur pemerintah desa bukan hanya himbauan agar kepala desa yang terpilih bisa lebih bijak dan lebih hati-hati dalam mengganti aparatur pemerintah desanya

Akibat dari aparatur pemerintah desa yang berganti-ganti tersebut ini mempengaruhi output atau hasil binaan yang telah dilakukan oleh program peningkatan kapasitas aparatur pemerintah desa. Hal tersebut membuat hasil pembinaan menjadi 0 dikarnakan setelah dilakukanya pembinaan kepada aparatur pemerintah desa, lalu aparatur pemerintah desa yang sudah dibina diganti dengan aparatur pemerintah desa yang baru yang belum terlatih.

Berikut ini adalah hasil wawancara dengan perwakilan desa yang ada di kabupaten subang, berikut adalah kutipan wawancara dengan pak rana selaku sekdes desa compreng yang diwawancarai pada tanggal 30 oktober 2019 pada pukul 11.00 WIB mengatakan bahwa:

"sudah semuanya mengikuti program peningkatan kapasitas aparatur desa, dan sudah sedkit sedikit kualitas aparatur desa meningkat, memang benar hambatanya adalah setiap setelah pilkades lalu kepala desa yang baru terpilih merombak perangkat desanya pernah dari dispendes mengajukan kenapa kok setiap pergantian kepala desa perangkat desa di ganti lagi kalau bisa di tetapkan jangan sampai diganti karana kalau sampai diganti hasil dari pembinaan kembali menjadi 0 lagi"

Selanjutnya wawancara dengan bapak rahmat Selaku sekdes desa cipancar kabupaten subang yang diwawancarai pada tanggal 31 oktober 2019 pada pukul 10.00 WIB mengatakan : 
“aparatur desa sudah mengikuti progrgram peningkatan kapasitas aparatur pemerintah desa tetapi belum seluruhnya mengikuti baru sebagian saja, program ini dapat meningatkan kemampuan aparatur desa program ini sangat membantu, kualitas nya belum seuai dengan apa yang diharapkan karena ada beberapa hambata salah satu nya dari keampuan dasar aparatur nya sendiri ada yang cepat mengikuti dan ada beberapa yang aga lambat mengikuti lalu hambatan lain seperti jika ada pegantian kepala desa kepala desa yang baru akan merubah semua susunan perangkat desanya sehingga perangkat desa yang baru belum cukup memadai kapasitasnya dan perlu waktu lagi untuk ditingkatkan kapasitasnya"

Sejalan dengan kutipan wawancara diatas, berikut adalah kutipan wawancara dengan Bapak sueb selaku kepala desa rancadaka kabupaten subang yang diwawancarai pada tanggal 4 november 2019 pada pukul 10.00 WIB mengatakan :

"kalau itu kebijakan politik saya sebagai kepala dea karena saya dipilih oleh masyarakat langsung suka tidak suka dukungan atas dukungan dari aparatur pemerintah desa juga sama memang sebelum pilkades kita sebagai calon sudah dihimbau sebelumnya untuk tidak mengganti aparatur yag sudah ada tapi bagaimana jika ada yang menghambat pada kinerja saya yam au tidak mau saya ganti dengan yang baru yang lebih bisa bejerja sama dengan saya"

Berdasarkan hasil wawancara dengan beberapa desa tersebut di atas bahwa memang benar jika kepala desa yang baru terpilih akan mengganti atau merombak aparatur pemerinah desa yang sudah ada sebelumnya diganti dengan yang baru hal ini dipengaruhi oleh proses politik pada saat pemilihan kepala desa berlangsung, yang di mana jika aparatur pemerintah desa yang lama tidak mendukung kepala desa yang baru pada saat pemilihan berlangsung dan akan mempengaruhi pada kinerja kepala desa tersebut maka kepala desa yang baru akan mengganti aparatur desa tersebut dengan yang baru.

Dari Berdasarkan beberapa pendapat di atas dapat disimpulkan berkaitan dengan produksi mengenai kualitas dan hasil output dari program peningkatan kapasitas aparatur pemerintah desa, belum berjalan efektif dkarenakan adanya beberapa permasalahan yang telah di ungkapkan, hasil dari program peningkatan kapasitas aparatur pemerintah desa belum sesuai dengan apa yang di harapkan.

\section{Efisiensi}

Efisiensi adalah sebagai perbandingan keluaran terhadap pemasukan. Kriteria jangka pendek ini memusatkan perhatian pada seluruh siklus input-proses-output, dengan menekankan pada elemen input dan proses. Ukuran efisiensi harus dinyatakan perbandingan output atau waktu.

Berkaitan dengan efisiensi program peningkatan kapasitas aparatur pemerintah desa peneliti berpendapat bahwa dari segi efisiensi anggaran belum berjalan dengan baik masih terdapat beberapa kendala. Dan berikut ini dibuktikan dengan kutipan 
wawancara dengan Dadan Dwiyana, A.P., M.Si. kepala bidang pemerintahan desa/kelurahan yang diwawancarai pada tanggal 25 oktober 2019 pada pukul 09.00 WIB mengatakan :

"mengenai anggaran sudah di upyakan seoptomal mungkin penyerapanya tetapi di lapangan faktanya masih belum bisa terserap 100\%, hal itu dikarenakan beberapa faktor mungkin salah satunya seperti lemahnya kordinasi antara perencanaan dan pelaksanaan anggaran hal itu berpotensi membuat serapan anggaran menjadi rendah, seperti contohnya untuk pelatihan dan pembinaan ternyata tidak di alokasikan anggaran untuk perjalanan.

Sejalan dengan kutipan wawancara di atas, berikut adalah kutipan wawancara dengan Mita S.AN selaku kasi tata pemerintahan desa/kelurahan yang diwawancarai pada tanggal 25 oktober 2019 pada pukul 10.00 WIB mengatakan :

“Anggaran dalam program peningkatan kapasitas aparatur pemerintah desa sudah realisasikan tetapi belum optimal realisasinya. Anggaran yang tidak terserap karena itu kan dibawah pagu yang karna efisiensi penawaran harga memang belum 100 persen karna faktor belanja, penawaran, dan faktor nego karna kalo ketika contohnya sewa tempat adanya penawaran lalu makan dan minum kita juga ada harga penawaran maka dari itu antara anggaran dan realisasi tidak persis"

Berdasarkan hasil wawancara tersebut diatas bahwa untuk efisiensi anggran program peningkatan kapasitas aparatur pemerintah desa sudah di usahakan agar terserap maksimal tetapi masih ada berbagai faktor yang mempengaruhi membuat penyerapan anggaran belum maksimal yang salah satunya faktor lemahnya kordinasi antara perencanaan dan pelaksanaan, belanja, penawaran, dan faktor nego hal tersebut membuat anggaran yang ada tidak dapat mencukupi untuk menjalankan seluruh kegiatan yang ada didalam program dikarena anggaran yang ada belum terserap maksimal.

Dari beberapa pendapat di atas dapat disimpulkan berkaitan dengan efisiensi antara anggaran dan realisasinya penyerapan anggaran belum terserap secara optimal dapat dikatakan belum efisien dikarenakan berbagai faktor yang sudah di sebutkan tadi sehingga akan berdapak langsung terhadap aparatur pemerintah desa karena program nya menjadi tersendat.

\section{Kepuasan}

kepuasan merupakan ukuran untuk menunjukan tingkat dimana organisasi dapat memenuhi kebutuhan karyawanya.

Berkaitan dengan kepuasan yaitu dilihat dari sarana dan prasarana pendukung peneliti berpendapat bahwa sarana dan prasarana sudah ada dan lengkap sarana dan prasarana yang dimaksudkan yaitu seperti gedung aula untuk pelaksanaan program berikut fasilitas yang ada didalamnya, dan kendaraan untuk transportasi. Berikut ini adalah kutipan wawancara dengan Dadan Dwiyana, A.P., M.Si. sebagai kepala bidang pemerintahan desa dan kelurahan pada tanggal 25 oktober 2019 pada pukul 09.00 WIB mengatakan : 
"Sarana dan prasarana di dinas sudah memadai seperti kendaraan sudah ada aula sudah ada audio sudah ada internet ada fasilitas multimedia sudah ada modul dipersiapkan dan narasumber juga kita persiapkan dengan pihak-pihak terkait"

Selanjutnya kutipan wawancara dengan wawancara dengan Mita S.AN selaku kasi tata pemerintahan desa/kelurahan yang diwawancarai pada tanggal 25 oktober 2019 pada pukul 10.00 WIB mengatakan :

"kalau sarana dan prasara yang belum ada untuk aplikasi modem dan server belum ada maka sulit untuk menggunakan aplikasi sehingga masih manual"

Dari hasil wawancara tersebut di atas, dapat diketahui bahwa sarana dan prasaran pendukung dalam program peningkatan kapasitas aparatur pemerintah desa sudah ada seperti kendaraan, aula, audio, internet, fasilitas multimedia, modul dan narasumber sudah di sediakan oleh dinas pemberdayaan masyarakat dan desa kabupaten subang.

Dengan sudah terlengkapi nya semua sarana dan prasarana pendukung untuk berjalanya program maka dari segi kepuasan yang berkaitan dengan sarana dan prasarana sudah terpenuhi.

Berikut ini merupakan hasil wawancara penulis dengan perwakilan desa yang ada di kabupaten subang, berikut adalah kutipan wawancara dengan pak rana selaku sekdes desa compreng yang diwawancarai pada tanggal 30 oktober 2019 pada pukul 11.00 WIB mengatakan bahwa:

"untuk fasilitas di desa sih sudah ada seperti gedung aula sudah ada tetapi kami msih berharap bisa lebih bagus dan lebih baik lagi dari apa yang sudah ada lebih bisa di perbaiki lagi"

selanjutnya kutipan wawancara dengan bapak rahmat Selaku sekdes desa cipancar kabupaten subang yang diwawancarai pada tanggal 31 oktober 2019 pada pukul 10.00 WIB mengatakan :

"untuk sarana dan prasarana di desa sudah lengkap seperti gedung serbaguna tetapi untuk fasilitas pendukunya masih masih perlu untuk di perbarui dan diperbagus lagi seperti ruanganya yang kurang bagus masih perlu untuk ditingkatkan lagi untuk kedepanya"

Sejalan dengan kutipan wawancara diatas, berikut adalah kutipan wawancara dengan Bapak sueb selaku kepala desa rancadaka kabupaten subang yang diwawancarai pada tanggal 4 november 2019 pada pukul 10.00 WIB mengatakan :

"sarana dan prasarana disini sudah ada seperti gedung aula untuk pelaksanaan kegiatan beserta alat-alat yang diperlukan untuk pelaksanaan kegiatan namun masih jauh dari kata bagus masih perlu ditingkatan lagi untuk kedepanya"

Berdasarkan hasil wawancara tersebut di atas bahwa dapat disimpulkan sarana dan peasarana yang ada di desa sudah terpenuhi. dari apa yang dipaparkan diatas dari beberapa desa tersebut sarana dan prasarana pendukung untuk program peningkatan kapasitas aparatur pemerintah desa sudah mencukupi. 
Dari beberapa pendapat di atas dapat disimpulkan berkaitan dengan kepuasan mengenai sarana dan prasarana untuk pendukung berjalanya program sudah terpenuhu walaupun bagunan masih perlu ditngkatkan lagi dan di perbagus lagi tetapi dengan bangunan dan fasilitas yang ada masih ckup untuk pendukung berjalanya program peningkatan kapasitas aparatur pemerintah desa.

\section{Adaptasi}

Adaptasi merupakan tingkat dimana organisasi dapat benar-benar tanggap terhadap perubahan internal maupun eksternal.

Berkaitan dengan adaptasi yaitu dilihat dari kemampuan untuk tanggap dalam menghadapi perubahan-perubahan peraturan undang-undang yang menjadi aspek yang disosialisasikan. Berikut ini adalah kutipan wawancara dengan Dadan Dwiyana, A.P., M.Si. sebagai kepala bidang pemerintahan desa dan kelurahan pada tanggal 25 oktober 2019 pada pukul 09.00 WIB mengatakan:

“aspek rujukan kita kan kalo ke desa peningkatan kapasitas tentang mengenai update pehahaman peraturan perundang-undangan jadi ketika peraturan perundang-undanganya berubah-ubah beda dengan pendidikan yang mempunyai kurikulum bakuyang masa berlakunya relatif panjang artinya kita pernah pengalaman tahun ini sosialisasi lalu setahun kemudian peraturanya sudah diganti jadi hasil peningkatan nol lagi nol lagi"

Sesuai dengan kutipan wawancara diatas, berikut ini kutipan wawancara dengan Mita S.AN selaku kasi tata pemerintahan desa/kelurahan yang diwawancarai pada tanggal 25 oktober 2019 pada pukul 10.00 WIB mengatakan :

“biasanya peraturan dari pusat kemendes atau kemendagri turun ke sini lalu nanti disampaikan ke desa tidak semuanya di rubah tapi ada ikhtisarnya yang dirubah perubahanya tidak mendasar kalau peraturan pusat secara umum nanti di atur lagi oleh peratran bupati nanti peraturan bupati yang dirujuk desa mengikuti peraturan bupati yang menginduk kepada peraturan pusat misalkan peraturan ADD itu di aturnya di daerah yang menginduk peraturan ke pusat perubahan itu biasanya terjadi tiap tahun sebelum pelaksanaan kecuali kalau tidak ada aturan baru mengikuti aturan yang lama"

Berdasarkan hasil wawancara tersebut di atas bahwa walaupun peraturan perundang-undang berganti dengan jangka waktu yang relatif cepat petugas pelaksana program dapat cepat mengikuti dan cepat mengsosialisasikanya ke desa, sehingga desa dapat terus mengetahui peraturan perundang-undangan yang baru.

Berikut ini hasil wawancara penulis dengan perwakilan desa yang ada di kabupaten subang, berikut ini adalah kutipan wawancara dengan pak rana selaku sekdes desa compreng yang diwawancarai pada tanggal 30 oktober 2019 pada pukul 11.00 WIB mengatakan bahwa:

"cepat kalo di sini biasanya begitu peraturan perundang-undangan keluar tentang tata kelola desa sebelum pelaksanaan program yang ada di desa lansung ada dari dinas yang mengsosialisasikan tentang tata kelola nya begitupun dengan dengan peaturan yang lain ada sosialisasinya" 
Selanjutnya adalah kutipan wawancara dengan bapak rahmat Selaku sekdes desa cipancar kabupaten subang yang diwawancarai pada tanggal 31 oktober 2019 pada pukul 10.00 WIB mengatakan :

"untuk sosialisasi peraturan perundang-undangan tentang tata kelola desa biasanya ada sosialisasi kesini dari dinas sebelum pelaksanaan program yang ada di desa biasanya dinas mengsosialisasikanya terlebih dahulu sebeum pelaksanaanya biasanya dilakukan setiap satu tahun sekali jika ada perubahan peraturan perundang-undangan"

Sejalan dengan kutipan wawancara di atan, berikut adalah kutipan wawancara dengan Bapak sueb selaku kepala desa rancadaka kabupaten subang yang diwawancarai pada tanggal 4 november 2019 pada pukul 10.00 WIB mengatakan :

"sosialisasi tentang peraturan yang baru sering dilakukan oleh dinas biasanya setelah peraturan perundang-undangan turun dari pusat langsung di sosialisasikan oleh dinas ke desa sebelum pelaksanaan program yang ada di sini"

Berdasarkan hasil wawancara tersebut di atas bahwa para petugas pelaksana program sudah cepat mengsosialisasikan peraturan perundang-undangan yang baru dikeluarkan oleh pemeritah.

Dari beberapa pendapat di atas dapat disimpulkan berkaitan dengan adaptasi mengenai kemampuan untuk tanggap dalam menghadapi perubahan-perubahan peraturan undang-undang yang menjadi aspek yang disosialisasikan pemerintah seharusnya dapat menetapkan peraturan yang sifatnya jangka panjang.

\section{Perkembangan}

Perkembangan merupakan mengukur kemampuan organisasi untuk meningkatkan kapasitasnya dalam menghadapi tuntutan lingkungan. Suatu organisasi harus melakukan berbagai upaya memperbesar kesempatan untuk kelangsungan hidup jangka panjang.

Berkaitan dengan perkembangan yaitu cara mempertahankan dan mengembangankan program peningkatan kapasitas aparatur pemerintah desa oleh dinas pemberdayaan masyarakat dan desa kabupaten subang berikut ini adalah kutipan wawancara dengan Dadan Dwiyana, A.P., M.Si. sebagai kepala bidang pemerintahan desa dan kelurahan pada tanggal 25 oktober 2019 pada pukul 09.00 WIB mengatakan :

"kami harus bekerja sama dengan semua pihak seperti pemerintah, tenaga pengajar, petugas pelaksana, lingkungan di desa dan aparatur pemerintah desa harus bersama-sama untuk bisa mempertahankan bahkan mengembangkan karena sangat sulit untuk terus untuk terus mengembangkanya apabila semua lapisan/pihak tidak ikut serta mendukung dan menyukseskan program ini" 
Sejalan dengan kutipan wawancara diatas berikut ini kutipan wawancara dengan Mita S.AN selaku kasi tata pemerintahan desa/kelurahan yang diwawancarai pada tanggal 25 oktober 2019 pada pukul 10.00 WIB mengatakan :

"selama kita bekerjasama dengan semua pihak dalam mengembangkan program peningkatan kapasitas aparatur pemerintah desa, kita yakin mampu untuk terus mengembangkanya agar pelaksanaan program ini terus berjalan efektif"

Berdasarkan hasil wawancara tersebut di atas bahwa program peningkatan kapasitas aparatur pemerintah desa dapat berkembang dan terus terus berjalan efektif apabila semua pihak yang terkait dalam program tersebut dapat bekerja sama dan terus mendukung berjalanya program peningkatan kapasitas aparatur pemerintah desa.

Selanjutnya wawancara penulis dengan perwakilan desa yang ada dikabupaten subang, berikut ini adalah kutipan wawancara dengan pak rana selaku sekdes desa compreng yang diwawancarai pada tanggal 30 oktober 2019 pada pukul 11.00 WIB mengatakan bahwa:

"dari waktu ke waktu dengan adanya program ini kemampuan kapasitas aparatur pemerintah desa terus meningkat kemampuanya mungkin dengan proses ini yang terus dilakukan kemampuan aparatur desa akan sesuai dengan apa yang diharapkan"

Sejalan dengan wawancara di atas, berikut adalah kutpan wawancara dengan bapak rahmat Selaku sekdes desa cipancar kabupaten subang yang diwawancarai pada tanggal 31 oktober 2019 pada pukul 10.00 WIB mengatakan :

"kemampuan aparatur pemerintah desa terus meningkat sejalan dengan proses pembinaan yang terus dilakukan aparatur pemerintah desa terus meningkat kualitasnya dari waktu ke waktu"

Sejalan dengan kutipan wawancara di atan, berikut adalah kutipan wawancara dengan Bapak sueb selaku kepala desa rancadaka kabupaten subang yang diwawancarai pada tanggal 4 november 2019 pada pukul 10.00 WIB mengatakan :

"seiring dilakukanya pembinaan dan pelatihan terhadap aparatur pemerintah desa tidak secara langsung aparatur desa bisa meningkat kapasitasnya perlu adanya proses pelatihan yang terus dilaksanakan jika terus dilaksanakan pasti aparatur pemerintah desa meningkat kapasitasnya"

Berdasarkan beberapa pendapat diatas dapat disimpulkan berkaitan dengan perkembangan mengenai cara untuk mempertahankan dan mengembangkan dinas pemberdayaan masyarakat dan desa kabupaten subang harus bisa bekerja sama dengan semua pihak yang terkait dalam program ini yaitu pemerintah, tenaga pengajar, petugas pelaksana program, desa, dan aparatur pemerintah desa apabila semuanya dapat bekerjasama dalam menyukseskan pelaksanaan program/kegiatan tersebut mampu meningkatkan kapasitas aparatur pemerintah desa agar pembangunan di desa terus meningkat serta pelayanan yang optimal dapat dilakukan. Dengan adanya pelaksanaan program peningkatan kapasitas aparatur pemerintah desa manfaat yang 
dirasakan oleh desa/kelurahan membantu aparatur pemerintah desa dan desa dalam meningkatkan kualitasnya.

\section{Pembahasan}

Berdasarkan hasil wawancara di atas dengan beberapa informan dan observasi peneliti, maka pada sub bab ini akan dibahas mengenai hasil wawancara dilapangan yang kemuduan dikaitkan dengan teori yang dikaji pada bab 2 sebelumnya. Dalam penelitian ini teori yang digunakan adalah ukuran efektivitas menurut pendapat Gibson (2002: 32) ada 5 indikator ukuran efektivitas yaitu produksi, efisiensi, kepuasan, adaptasi, dan perkembangan.

\section{Pembahasan Pada Dimensi Produksi}

Menurut Gibson produksi menggambarkan kemampuan organisasi untuk memproduksi jumlah dan mutu output yang sesuai dengan permintaan lingkungan. Ukuran tentang produksi meliputi laba, penjualan, bagian pasar, mahasiswa yang lulus, pasien yang sembuh, pelanggan yang dilayani dan sebagainya. Ukuran ini berhubungan secara langsung dengan output yang dihasilkan oleh organisasi. Dari hasil penelitian dilapangan tidak sejalan dengan teori yang dikemukakan oleh Gibson tersebut, hal ini dibuktikan dengan belum seluruhnya aparatur pemerintah desa sudah mengikuti pembinaan dan pelatihan yang dilaksanakan dalam program ini dikarenakan aparatur desa yang bergant-ganti setiap kepala desa yang baru terpilih.

\section{Pembahasan Dimensi Efisiensi}

Menurut Gibson perbandingan keluaran terhadap masukan. Kriteria jangka pendek ini memusatkan perhatian pada seluruh siklus input-proses-output, dengan menekankan pada elemen input dan proses. Ukuran efisiensi harus dinyatakan perbandingan output atau waktu. Dari hasil penelitian di lapangan tidak sejalan dengan teori yang dikemukakan oleh Gibson tersebut, hal ini dibuktikan dengan rasio angaran dengan realisasi anggaran belum sepenuhnya terserap sehingga sehingga akan berdapak langsung terhadap aparatur pemerintah desa karena program nya menjadi tersendat

\section{Pembahasan Dimensi Kepuasan}

Menurut Gibson ukuran untuk menunjukan tingkat dimana organisasi dapat memenuhi kebutuan masyarakat atau karyawanya. Dari hasil penelitian dilapangan sejalan dengan teori yang dikemukakan Gibson tersebut, hal ini dibuktikan dengan semua sarana dan prasarana sudah ada hanya beberapa fasilitas pendukung nya saja lebih bisa ditingkatkan.

\section{Pembahasan Dimensi Adaptasi}

Menurut Gibson tingkat dimana organisasi dapat dan benar-benar tanggap terhadap perubahan internal dan eksternal. Dari hasil penelitian dilapangan sejalan dengan dengan teori yang dikemukakan oleh Gibson tersebut, hal ini dibuktikan dengan program peningkatan kapasitas aparatur pemerintah desa dapat mengsosialisasikanya dengan cepat walauput peraturam perundang-undangan dari 
pemerintah tentang tata kelola desa terus berganti-ganti dengan jangka waktu yang relatif cepat.

\section{Pembahasan pada dimensi perkembangan}

Menurut Gibson mengukur kemampuan organisasi untuk meningkatkan kapasitanya dalam menghadapi tuntutan lingkungan. Suatu organisasi harus melakukan berbagai upaya memperbesar kesempatan untuk kelangsunga hidup jangka panjang. Dari hasil penelitian di lapangan sejalan dengan teori yang dikemukakan Gibson tersebut, hal ini dibuktikan dengan selama semua pihak bekerjasama dalam menjalankan program atau kegiatan tersebut hal ini dapat mampu meningkatkan, mempertahankan, dan mengembangkanya, dalam proses pelatihan dan pembinaan aparatur pemerintah desa agar dapat terus membangun desanya menjai lebih unggul dan dapat meningkatkan pelayan di desa yang optimal. Dengan adanya pelaksanaan program peningkatan kapasitas aparatur pemerintah desa manfaat yang dirasakan oleh desa membantu aparatur pemerintah desa untuk terus meningkatkan kualitas dan kapasitasnya dalam membangun desa dan pelayanan desa.

Berdasarkan hasil hasil pembahasan dari 5 dimensi efektivitas menurut Gibson. Pada dimensi Produksi dari penelitian di lapangan belum berjalan dengan baik hal ini dibuktikan dengan belum seluruhnya aparatur pemerintah desa di sudah mengikuti pembinaan dan pelatihan yang dilaksanakan dalam program ini dikarenakan aparatur desa yang bergant-ganti setiap kepala desa yang baru terpilih. Kemudian pada dimensi Efisiensi dari hasil penelitian di lapangan belum berjalan dengan baik hal ini dibuktikan dengan rasio angaran dengan realisasi anggaran belum sepenuhnya terserap sehingga angaaran yang ada bellum mencukupi untuk pelaksanaan program. Kemudian pada dimensi Kepuasan dari hasil penelitian dilapangan sudah berjalan dengan baik hal ini dibuktikan dengan sejalan dengan teori yang dikemukakan Gibson tersebut, hal ini dibuktikan dengan semua sarana dan prasarana pendukung untuk berjalanya program sudah ada hanya beberapa fasilitas pendukung nya saja lebih bisa ditingkatkan. Kemudian pada dimensi Adaptasi dari hasil penelitian dilapangan sudah berjalan dengan baik ini dibuktikan dengan program peningkatan kapasitas aparatur pemerintah desa dapat mengsosialisasikanya dengan cepat walaupun peraturam perundang-undangan dari pemerintah tentang tata kelola desa terus berganti-ganti dengan jangka waktu yang relatif cepat. Dan dimensi yang terakhir yaitu dimensi perkembangan, dari hasil penelitian dilapangan sejalan selama semua pihak bekerjasama dalam menjalankan program atau kegiatan tersebut hal ini dapat mampu meningkatkan, mempertahankan, dan mengembangkanya, dalam proses pelatiha dan pembinaan aparatur pemerintah desa agar dapat terus membangun desanya menjai lebih unggul dan dapat meningkatkan pelayan di desa yang optimal. Dengan adanya pelaksanaan program peningkatan kapasitas aparatur pemerintah desa manfaat yang dirasakan oleh desa membantu aparatur pemerintah desa untuk terus meningkatkan kualitas dan kapasitasnya dalam membangun desa dan pelayanan desa.

Berdasarkan ke lima dimensi efektivitas menurut Gibson diatas, peneliti menemukan 2 dimensi yang belum sejalan dengan teori yang dikemukaka oleh Gibson yaitu pada dimensi 1) Produksi, 2) Efisiensi, dan yang sudah sesuai denga teori 
efektivitas yang dikemukakan oleh Gibson yaitu pada dimensi 1) Kepuasan 2) Adaptasi 3) Perkembangan. Efektivitas Program Peningkatan Kapasitas Aparatur Pemerintah Desa oleh Dinas Pemberdayaan Masyarakat dan Desa Kabupaten Subang belum sepenuhnya mengarah pada teori Efektifitas Gibson (2002: 32). Hal itu dibuktikan dengan belum seluruhnya aparatur pemerintah desa sudah mengikuti pembinaan dan pelatihan yang dilaksanakan dalam program ini dikarenakan aparatur desa yang bergant-ganti setiap kepala desa yang baru terpilih. Rasio angaran dengan realisasi anggaran belum sepenuhnya terserap sehingga angaaran yang ada bellum mencukupi untuk pelaksanaan program.

\section{Kesimpulan}

Berdasarkan hasil penelitian dan pembahasan yang telah dilakukan pada bab sebelumnya mengenai Efektivitas Program Peningkatan Kapasitas Aparatur pemerintah Desa oleh Dinas Pemberdayaan Masyarakat dan Desa Kabupaten Subang, peneliti menggunakan pendekatan kualitatif dan menggunakan teori Gibson agar dapat memberikan penilaian terhadap Program Peningkatan Kapasitas Aparatur Pemerintah Desa maka dapat disimpulkan sebagai berikut:

1. Produktivitas

Pada dimensi produktivitas dalam pelaksanaan program peningkatan kapasitas aparatur prmerintah desa sudah berjalan hanya saja belum baik dan belum sepenuhnya berhasil mencapai tujuan, karena dalam tahapan pelaksanaan program peningkatan kapasitas aparatur pemerintah desa masih terdapat adanya kendala, dan hasil belum sesuai dengan apa yang diharapkan sehingga program peningkatan kapasitas aparatur pemerintah desa belum efektif.

2. Efisiensi

Pada dimensi Efisiensi dalam program peningkatan kapasitas aparatur pemerintah desa sudah berjalan hanya saja belum baik dan belum sepenuhnya mencapai tujuan, karena dalam pelaksaaan program peningkatan kapasitas aparatur pemerintah desa masih terdapat adanya kendala, dan efisiensi anggaran belum optimal sehingga sehingga pelaksanaan program peningkatan kapasitas aparatur pemerintah desa belum efektif.

3. Kepuasan

Pada dimensi kepuasan mengenai sarana dan prasarana yang digunakan dalam program peningkatan kapasitas aparatur pemerintah desa sudah tersedia semua hanya saja beberapa fasilitas pendukungnya perlu ditingkatkan dan diperbaharui.

4. Adaptasi

Pada dimensi adaptasi dalam pelaksanaan program peningkatan kapasitas aparatur pemerintah desa sudah bisa cepat menyesuaikan dalam menghadipi peraturan perundang-undangan yang menjadi aspek untuk disosialisasikan tentang tata kelola desa yang berubah dalam jangka waktu yang cepat.

5. Perkembangan 
Dalam dimensi perkembangan dinas pemberdayaan masyarakat dan desa kabupaten subang yakin apabila semua lapisan desa ikut serta mendukung dapat bekerja sama untuk terus mengembangkan serta mensukseskan program ini.

\section{Referensi}

Adisasmita Rahardjo. 2006. Pembangunan Pedesaan dan Perkantoran. Yogyakarta: Graha Ilmu

Charles O. Jones. 1996. Pengantar Kebijakan Publik. Jakarta, PT Raja Grafindo Persada. dalam ejurnal Ramandita Shalfiah. 2013. Peran Pemberdayaan dan Kesejahteraan Keluarga (PKK) dalam mendukung Program-Program Pemerintah kota Bontang. ISSN 2338-3615. 978. Vol. 3. Hal. 975-984.

Georgopoulos dan Tennenbaum. 2005. Efektivitas Organisasi. Jakarta: Erlangga

Gibson, James, 2002. Organisasi dan Manajemen. Jakarta: Gunung Agung.

Hadayaningrat Soewarno. 2006. Pengantar Studi Ilmu Administrasi dan Manajemen. Jakarta: Gunung Agung

Hasanah Budi, Sururi Ahmad. 2018. Peningkatan Kapasitas Aparatur Pemerintah Desa dan Masyarakat Melalui Pelatihan Administrasi Pemerintahan di Desa Sukamenak Kecamatan Cikeusal Kabupaten Serang. Jurnal Pengabdian Masyarakat. e-ISSN 2599-0012. Researchgate.net. 23 November 2018

Haw Widjaja, 2004, Otonomi Desa. Jakarta: PT RajaGrafindo Persada

Moleong, Lexy. 2000. Metodelogi Penelitian Kualitatif. Bandung: PT. Remaja Rosada Karya.

Miles dan Huberman 1994. Qualitative Data Analysis. Diterjemahkan Tjetjep Rohendi, Analisis Data Kualitatif. Jakarta: UI Press.

Martani dan Lubis. 2007. Teori Organisasi: Perspektif makro. Pusat Antar Universitas Universitas Indonesia.

Nazir, 2011. Metode Penelitian. Bogor: Ghalia Indonesia

Pasolong, Harbani. 2007. Teori Administrasi Publik. Bandung: Alfabeta.

Satori dan Komariah. 2010. Metodologi Penelitian Kualitatif. Bandung: Alfabeta, CV

Steers, Richard M. 2003. Efektifitas Organisasi. Jakarta: Erlangga.

Sutarto. 2007. Dasar-Dasar Organisasi. Yogyakarta: Gadjah Mada University Press.

Sutrisno,Edy. 2011. Budaya Organisasi. Jakarta: Kencana Prenada Media Group

Siagian, Sondang P. 2008. Manajemen sumber daya manusia. Jakarta: PT Bumi Aksara 


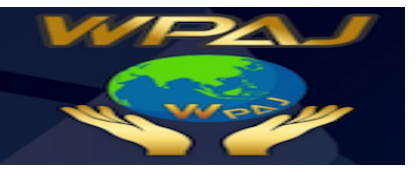

Volume 1 Issue 2, Desember 2019

Siagian, Sondang P. 2006. Filsafat Administrasi. Jakarta: CV . Haji Mas Agung. Sugiyono, 2015. Metode Penelitian dan Pembangunan. Bandung: Alfabeta, CV

Suyanto Bagong. 2005. Metode Penelitian Sosial:Berbagai Alternatif Pendekatan. Jakarta: Prenada Media.

Tangkilisan, Hessel Nogi S. 2005. Manajemen Publik. Jakarta: Gramedia Widia Sarana Indonesia

The Liang Gie. 2002. Ensiklopedia Administrasi. Jakarta: PT.Gunung Agung.

Tayibnapis, Farida Yusuf. 2000. Evaluasi Program. Jakarta: PT. Rineka Cipta.

Ulum, Ihyaul. 2009. Manajemen teori. Praktik, dan Riset Pendidikan. Jakarta: Bumi Aksara

Undang-Undang Republik Indonesia Nomor 6 Tahun 2014 tentang Desa

Wina Sanjaya. 2002. Metodelogi Penelitian Pendidikan: Bandung: San Grafika 